\title{
EVALUATION OF MEMORY-ENHANCING ACTIVITY FOR ERYTHRININE FROM LEAF EXTRACT OF ERYTHRINA INDICA
}

\author{
KAMALRAJ $\mathbf{R}^{1 *}$, SUBHASHREE G $\mathbf{R}^{2}$ \\ ${ }^{1}$ PEH R and D, Pfizer Inc., Chennai, Tamil Nadu, India. ${ }^{2}$ Department of Physics, Dr. MGR Educational and Research Institute, Chennai, \\ Tamil Nadu, India. Email: kamalrajkbt@gmail.com
}

Received: 14 January 2019, Revised and Accepted: 19 March 2019

\section{ABSTRACT}

Objective: The objective of the study was to investigate the memory-enhancing activity for erythrinine (ring-c-oxygenated Erythrina alkaloid) from leaf extract of Erythrina indica in mice.

Methods: The study protocol designed in the way that it was carried out for 21 successive days by administrating the $5 \mathrm{mg} / \mathrm{kg}$, s.c doses of isolated erythrinine to mice and the profile was challenged against the mice feeds with normal saline as a positive control and the mice treated with $5 \mathrm{mg} / \mathrm{kg}$, s.c corticosterone as a negative control for the amnesia using Morris water maze test method.

Results: Erythrinine-administered mice are showing remarkable retention of the memory $(9.07 \pm 0.52)$ on the $21^{\text {st }}$ day as such of the positive control normal saline $(10.14 \pm 0.22)$ and against the negative control corticosterone-injected mice $(70.86 \pm 0.54)$.

Conclusions: The dose of $5 \mathrm{mg} / \mathrm{kg}$ s.c of isolated erythrinine from the leaf of $E$. indica shows the remarkable memory enhancement when it was investigated with the memory weakening induced test by corticosterone in mice's using $5 \mathrm{mg} / \mathrm{kg}$ s.c. However, further studies required to elucidate the exact mechanism of action for developing its as potent memory-enhancing drug.

Keywords: Erythrinine, Memory enhancing, Amnesia.

(c) 2019 The Authors. Published by Innovare Academic Sciences Pvt Ltd. This is an open access article under the CC BY license (http://creativecommons. org/licenses/by/4. 0/) DOI: http://dx.doi.org/10.22159/ajpcr.2019.v12i5.32052

\section{INTRODUCTION}

Alzheimer's disease (AD) is a neurological brain disorder. AD is also known as dementia, a group of disorders that impair mental functioning. Memory loss is one of the earliest symptoms, along with a gradual decline of proper thinking abilities called cognitive function and change in personality [1-3].

On early stage of the person with Alzheimer disease, may have the symptoms like difficulty in remembering the daily planned activities and misperception (short term memory loss). On long term, the disease slowly goes worst such as start forgetting the words, language, loss of motivation, and faced behavioral issue in the society which may gradually isolated from the family and society and as a worst cause ultimately leading to death $[4,5]$.

The exact causes of the AD were still under investigation, and most of the history of investigation is outcome reason as genetic or any inadvertent injuries and over the period of hypertension or depression [6].

Yoga, physical exercise, and creating the stress-free environment such as listening music, reading books, and maintain the stabilized blood pressure may help to decrease the threat of AD still there are no medications or supplements that used to decrease risk immediately [7].

Treating the people with antipsychotics drugs is recommended for the behavioral problems and psychosis due to dementia, but not usually recommended due to its adverse risks $[8,9]$.

Inearlystudies, different parts of Erythrinaand Erythrinaalkaloids are used as a traditional medicine in various diseases such as anti-inflammatory, antioxidant, sedative, antiasthmatic, and antiepileptic [10,11].

Even in our previous research, we proved the antihyperlipidemic, convulsion, and stress-induced alteration on lipid profile in rats using the leaf extract of Erythrina indica [12]
From the source of literature, we found the extract of Erythrina variegate already proved for the memory-enhancing activity and manages the dementia [13].

In continuation of our research, we attempt early erythrinine for its Insilco evaluation and QSAR studies. To explore further medicinal uses of the isolated erythrinine from the leaf extract of the E. indica, an attempt was made to carry out the memory-enhancing effect to confirm the specific activity from the individual Erythrina alkaloids (erythrinine).

\section{MATERIALS AND METHODS}

\section{Material used}

The fresh leaf of $E$. indica was collected from the mature plant in and around the city of Chennai, Tamil Nadu, India, and dried under shade. The plant was authenticated by Dr. Sasikala, Department of Pharmacognosy, Captain Srinivasamoorty Drug Research Institute of Ayurveda, Chennai [12].

\section{Isolation of erythrinine}

The powdered, air-dried leaf of E. indica was first extracted with hexane and then with methanol, and the alkaloids subsequently isolated by treating the crude leaf extracts of E. indica with $1 \%$ hydrochloric acid, followed by basification and extraction with chloroform. The alkaloidal fraction obtained from the methanol extract was fractionated by column chromatography on Sephadex LH 20 to yield a crystalline substance erythrinine with $85-90 \%$ purity (Fig. 1) [14-16].

\section{Animal's used}

Male albino mice (25-40 g) were used for the proposed study. All the mice are well maintained in a ventilated room with suitable alternate source for light/dark cycle in polypropylene cages. The mice were free access to food and water. The standard pellet feed from Hindustan Lever 
Limited, Bangalore, was used to feed for the mice to acclimatize for at least week before experimentation. Ethical committee clearance was obtained from the Institutional Animal Ethics Committee of CPCSEA and all cares were followed as per regulation.

\section{Study plan}

Experiments were designed as three groups, each group of six male albino mice with that the weight range of $25-40 \mathrm{~g}$. The test drug, isolated erythrinine $5 \mathrm{mg} / \mathrm{kg}$ s.c doses were administered for 21 days in sequence as per study plan, 30 min before administration of corticosterone injection which is used as negative control. Corticosterone ( $5 \mathrm{mg} / \mathrm{kg}$ ) was dissolved in absolute ethanol and subsequently diluted in water to the final concentration of $10 \%$ ethanol and injected subcutaneously in a volume of $1 \mathrm{ml} / \mathrm{kg}[17,18]$.

- Group-I: Positive control (Normal saline $2 \mathrm{ml} / \mathrm{kg}$, p.o [0.9\% w/v]).

- Group-II: Negative control (Corticosterone inj., $5 \mathrm{mg} / \mathrm{kg} \mathrm{s.c)}$.

- Group-III: $5 \mathrm{mg} / \mathrm{kg}$ s.c doses of isolated erythrinine for 21 days, $30 \mathrm{~min}$ before corticosterone administration ( $5 \mathrm{mg} / \mathrm{kg} \mathrm{s.c}$ ).

\section{Morris water maze test}

\section{Setting up the water maze}

Water maze is set up as a round pool, about 6 feet in diameter and about 3 feet deep. Filled the water maze with tap water, which should be close to $26^{\circ} \mathrm{C}$. Placed the escape platform in the center of the pool. During training, it must be exposed, 1 inch above the water. This teaches the mice are that there is a platform and that it is the way to get out of the water [13].

Then, escape platform was hidden and will not be visible color change due to milk. Pre-training for animals was given as per standard procedure [18].

\section{Water maze testing}

During execution of the experiments, the pool was added with milk for color difference with water and to differ from the training. The circular pool was filled up to $30 \mathrm{~cm}$ in height and maintained the temperature of $18^{\circ} \mathrm{C}$. A white platform (6 cm in diameter and $29 \mathrm{~cm}$ in height) was centered in one of four quadrants of the pool (Southeast area) and submerged $1 \mathrm{~cm}$ below the water surface so that it was invisible at water level. In the water maze experiments, the $1^{\text {st }}$ week of the experiment was dedicated to swimming training for $60 \mathrm{~s}$ for all group mice. Remaining

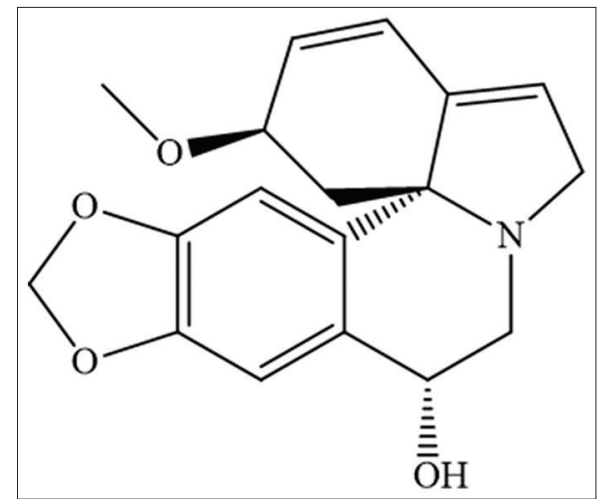

Fig. 1: Structure of erythrinine
3 weeks of treatment were investigated with all the groups. In these days, the mice were given one session of two trails each day for 21 days. During each trial, the mouse's escape latency, measured with a stopwatch, was recorded. In each group, six mice were allowed for investigation and the parameter was averaged for each session of trials and for each mouse. If any one of the mice is located the correct platform earlier to 120 s, will allow to remain the platform for $10 \mathrm{~s}$ and note the readings. If the mice not identified the correct platform within $120 \mathrm{~s}$, it was reseated for $10 \mathrm{~s}$ on the platform for a break. The platforms are rearranged and bring back to testing condition and fixed position for next trail. The same testing was studied for more than each day up to 21 days study periods and all the parameters are noted. As a climax of the study protocol, on the 21 days, mice were given a probe trial which considered of removing the platform from the pool and allowing the mice to swim for $60 \mathrm{~s}$ in search of it and the outcome of the results and recorded. All the records calculated the swimming time of the mice in the pool quadrant, where the platform had previously been placed. Isolated erythrinine was administered subcutaneously 10 min before the consecutive training.

\section{Statistical analysis}

The statistical significance of the results of Morris water maze was analyzed using ANOVA, followed by Dunnett's test, $\mathrm{p}<0.05$ was considered as statistical significance.

\section{RESULTS}

The study protocol designed in the way it was carried out for 21 successive days by administrating the $5 \mathrm{mg} / \mathrm{kg}$, s.c doses of isolated erythrinine to mice and the profile was challenged against the mice feeds with normal saline as a positive control and the mice treated with $5 \mathrm{mg} / \mathrm{kg}$, s.c corticosterone as a negative control for the amnesia using Morris water maze teat method. Erythrinine-administered mice are showing sowing remarkable retention of the memory $(9.07 \pm 0.52)$ on the $21^{\text {st }}$ day as such of the positive control normal saline $(10.14 \pm 0.22)$ and against the negative control corticosterone-injected mice $(70.86 \pm 0.54)$.

Positive control mice administered only with the normal saline (Group I), identified the same submerged platform as same as from the $1^{\text {st }}$ day $(13.14 \pm 0.25)$ and $21^{\text {st }}$ day $(10.14 \pm 0.22)$ with minimal change with remarkable transfer latency. When administering only corticosterone injection $(5 \mathrm{mg} / \mathrm{kg})$ group which act as a negative control, will show the memory impairment rapidly from the $0^{\text {th }}$ day $(9.76 \pm 0.32)$ to $21^{\text {st }}(70.86 \pm 0.54)$ which will be higher rate when compare with the only saline treated mice's. Isolated erythrinine treated mice $(5 \mathrm{mg} / \mathrm{kg}$ ) shown good response in identifying the platform compare to Corticosterone injected mice's and also pointedly than the saline treated mice's from $9^{\text {th }}(15.97 \pm 0.27)$ day to $21^{\text {st }}(9.07 \pm 0.52)$ day which means the mice's start to response to the Isolated Erythrinine from the $9^{\text {th }}$ day and when $21^{\text {st }}$ day it shows the its show the equal response as such of saline only treated group $(10.14 \pm 0.22)$, Where has when it compared with the corticosterone only injected group shows impairment approx. 7 times $(70.86 \pm 0.54)$ (Table 1$)$. The above results confirm that the isolated erythrinine-injected mice $(9.07 \pm 0.52)$ are having learning and memory-enhancing properties.

\section{DISCUSSION AND CONCLUSIONS}

The isolated erythrinine from the leaf of $E$. indica shows the remarkable memory enhancement when it was investigated with the memory

Table 1: Effect of isolated erythrinine transfer latencies of mice on Morris water maze test

\begin{tabular}{|c|c|c|c|c|c|c|c|c|c|}
\hline \multirow[t]{2}{*}{ Group } & \multirow[t]{2}{*}{ Treatment } & \multicolumn{8}{|c|}{ Transfer latency (s) } \\
\hline & & $\mathbf{0}$ & 3 & 6 & 9 & 12 & 15 & 18 & 21 \\
\hline I & Normal saline 2 mL/kg, p.o & $13.14 \pm 0.25$ & $15.14 \pm 0.87$ & $13.98 \pm 0.52 *$ & $12.14 \pm 0.59 *$ & $11.14 \pm 0.82 *$ & $11.64 \pm 0.52^{*}$ & $13.74 \pm 0.52 *$ & $10.14 \pm 0.22 *$ \\
\hline II & Corticosterone $5 \mathrm{mg} / \mathrm{kg}$, s.c & $9.76 \pm 0.32$ & $14.00 \pm 0.52$ & $25.04 \pm 0.22$ & $36.04 \pm 0.52$ & $49.25 \pm 0.47$ & $56.87 \pm 0.52$ & $67.34 \pm 0.92$ & $70.86 \pm 0.54$ \\
\hline III & $\begin{array}{l}\text { Corticosterone+isolated } \\
\text { erythrinine } 5 \mathrm{mg} / \mathrm{kg} \mathrm{s.c}\end{array}$ & $7.87 \pm 0.52$ & $9.14 \pm 0.72$ & $12.84 \pm 0.52$ & $15.97 \pm 0.27$ & $12.74 \pm 0.52 *$ & $11.76 \pm 0.98^{*}$ & $11.34 \pm 0.82 *$ & $9.07 \pm 0.52^{*}$ \\
\hline
\end{tabular}


weakening induced test by corticosterone in mice using $5 \mathrm{mg} / \mathrm{kg}$ s.c. The dose of $5 \mathrm{mg} / \mathrm{kg}$ s.c of isolated erythrinine was challenged with the only saline group mice as positive control and corticosterone only administered mice as a negative control and established results proved that the dose of $5 \mathrm{mg} / \mathrm{kg}$ s.c having the memory-enhancing property and used in the treatment of dementia.

The probable mechanism of action, form literature is discussed in brief below. Corticosterone significantly impaired other forms of hippocampus-dependent memory such as object recognition and retrieval of the passive avoidance behavior. Corticosterone, the predominant glucocorticoid in rodents, chronic administration of corticosterone it damages hippocampal subregion CA3 that leads to impair spatial memory. Also chronically elevated levels of corticosterone injection administration is mice for 21 days can produce neuronal atrophy and cell death in the hippocampus while leaving other brain regions, the elevated levels of corticosterone changes in various neurotransmitters such as catecholamine's, serotonin and aminobutyric acid (GABA) in several brain structures. In the hippocampus, corticosterone impairs GABA-mediated inhibitory neurotransmission and causes neurodegeneration through diminished expression of GABAA receptors. High amounts of corticosterone enhance action of norepinephrine through adrenal receptors and increased dopamine turnover in prefrontal cortex is accompanied by the decreased spatial memory performance $[3,15]$.

Erythrinine is a ring-c-oxygenated Erythrina alkaloid which acts as inhibition of ache and increases the acetylcholine level in the brain through the involvement of GABA-benzodiazepine pathway virtue of which susceptible brain cells get exposed to less oxidative stress resulting in reduced brain damage and improved neuronal function, thereby enhancing the memory activity. However, further studies required to elucidate the exact mechanism of action for developing its as potent memory-enha ncing drug [3].

\section{ACKNOWLEDGMENT}

The authors are thankful to Vels University (VISTAS), Dr. MGR Educational and Research Institute and its management for providing research facilities and encouragement.

\section{AUTHORS' CONTRIBUTIONS}

Both authors having equal contribution in overall studies.

\section{CONFLICTS OF INTEREST}

The authors declare that they have no conflicts of interest.

\section{REFERENCES}

1. Burns A, Life S. Alzheimer's disease. BMJ 2009;338:b158.

2. World Health Organization. Dementia Fact sheet N 362. Geneva: World Health Organization; 2015

3. Pratap GK, Ashwini S, Shantaram M. Alzheimer's disease: A challenge in managing with certain medicinal plants-a review. IJPSR 2017; $8: 4960-72$

4. National Institute on Aging. Alzheimer's Disease Diagnostic Guidelines; 2011.

5. Querfurth HW, LaFerla FM. Alzheimer's disease. N Engl J Med 2010;362:329-44.

6. NICE. Dementia Diagnosis and Assessment. UK: National Institute for Health and Care Excellence (NICE); 2014

7. Ballard C, Gauthier S, Corbett A, Brayne C, Aarsland D, Jones E, et al. Alzheimer's disease. Lancet 2011;377:1019-31.

8. Todd S, Barr S, Roberts M, Passmore AP. Survival in dementia and predictors of mortality: A review. Int J Geriatr Psychiatry 2013;28:1109-24.

9. Anonymous. University of Florida: Environmental Horticulture; 2008

10. Subhashini N, Nagarajan G, Kavimani S. In vitro antioxidant and anticholinesterase activities of Garcinia combogia. Int J Pharm Pharm Sci 2011;3:129-32

11. Krishna VR, Tejaswini G. Anti-inflammatory activity of Erythrina variegata. Int J Pharm Pharm Sci 2015;7:386-8.

12. Kamalraj R, Muthukumar VA. Effect of Erythrina indica on stress induced alteration on lipid profile in rats. Asian Pacific J Trop Dis 2012;2:S949-51.

13. Srinivasan N, Sriram N, Mandtry S, Kumar SA, Yashoda K. Memory enhancing activity of Erythrina variegate on corticosterone induced dementia in mice. Int J Pharmacol Screen Methods 2013;3:72-6.

14. Ito K, Haruna M, Jinno, Furukawa. The alkaloids: Chemistry and pharmacology. H Chem Phurm Bull 1976;24:52.

15. Dagne E, Steglich W. 8-oxoerythrinine: An alkaloid from Erythrina brucei. Phytochemistry 1984:23;449-51.

16. Ito $\mathrm{K}$, Haruna M, Furukawa J. The isoquinoline alkaloids chemistry and pharmacology. J Chem Sot Chem Commun 1970;1076:119.

17. Wang J, Zhang HY, Tang XC. Cholinergic deficiency involved in vascular dementia, possible mechanism and strategy of treatment. Acta Pharmacol Sin 2009;30:1671-4083.

18. Rubio J, Dang H, Gong M, Liu X, Chen SL, Gonzales GF, et al. Aqueous and hydroalcoholic extracts of black Maca (Lepidium meyenii) improve scopolamine-induced memory impairment in mice. Food Chem Toxicol 2007;45:1882-90. 